\title{
Macrocrustaceans associated with reefs of Phragmatopoma caudata Krøyer in Mörch, 1863 (Polychaeta: Sabellariidae) and rocky shore in the Northeastern Brazil
}

\author{
Laiane Lane-Medeiros ${ }^{1,3}$; Carolina Teixeira Puppin-Gonçalves ${ }^{1,4}$; Matheus Arthur Lúcio da Rocha ${ }^{1,5}$; \\ Carlos Eduardo Rocha Duarte Alencar ${ }^{1,2,6}$ \& Fúlvio Aurélio de Morais Freire ${ }^{1,7}$
}

\footnotetext{
1 Universidade Federal do Rio Grande do Norte (UFRN), Centro de Biociências (CB), Departamento de Botânica e Zoologia (DBEZ), Laboratório de Biologia, Ecologia e Evolução de Crustáceos (LABEEC). Natal, RN, Brasil.

${ }^{2}$ Universidade Regional do Cariri (URCA), Centro de Ciências Biológicas e da Saúde (CCBS), Departamento de Ciências Biológicas (DCB), Laboratório de Crustáceos do Semiárido (LACRUSE). Crato, CE, Brasil.

3 ORCID: http://orcid.org/0000-0001-6645-1953. E-mail: laimdrs7@gmail.com (corresponding author)

${ }^{4}$ ORCID: http://orcid.org/0000-0002-9875-9984. E-mail: carolpuppin@gmail.com

${ }^{5}$ ORCID: http://orcid.org/0000-0003-3742-5101. E-mail: matheusarthurrocha@outlook.com

${ }^{6}$ ORCID: http://orcid.org/0000-0003-4231-4326. E-mail: carlosce2002@gmail.com

7 ORCID: http://orcid.org/0000-0003-1580-0222. E-mail: fulvioamf@gmail.com
}

\begin{abstract}
Ecosystem engineering species create, modify, and/or maintain the characteristics of the environment. The polychaete Phragmatopoma caudata builds large sand reefs in the intertidal region of the Brazilian coast with high structural complexity, favoring the increase of diversity and interactions among the species associated. However, there are no studies concerning the association of polychaetes with crustacean macrofauna in the northeastern Brazil ecoregion, leaving an information gap on baseline biodiversity. Our aim was to analyze the effect of $P$. caudata colonies (PC) on the local diversity of macrocrustaceans compared to the rocky shore (RS) microhabitat. Monthly collections were carried out in low tide from September 2015 to August 2016 on $10 \times 10 \mathrm{~m}$ quadrants for fauna and environmental variables (temperature and salinity) samples. In each microhabitat, the capture effort was two hours by two researchers. We collected 3,390 individuals, $60 \%$ associated with the colonies of PC and 40\% with the RS. The PC obtained higher Shannon diversity, Pielou evenness and species richness coupled with milder water temperature and salinity conditions (minor air exposure during tide), compared to the RS that obtained greater species dominance and more extreme abiotic conditions (major air exposure). The Porcellanidae family stood out because all its species were highly abundant and had high occurrence in the colonies. The tropical Brazil porcelain crab Pachycheles greeleyi was dominant in both microhabitats (major dominance in PC). The structural complexity in the reefs of $\mathrm{PC}$ promoted higher availability of niches for the species, as more shelter for the resident species and refugium for temporary species with preference for more complex microhabitats. Conservation managers should prioritize the health of these colonies and subsequent species that constitute important ecosystemic and fishery resources.
\end{abstract}

Keywords. Structural complexity; Shelter; Refugium; Porcellanidae; Decapoda; Ecosystem engineering.

\section{INTRODUCTION}

An ecosystem engineer is a species capable to create, modify and maintain the characteristics of the environment and have a direct or indirect impact on the physical structure, resources, complexity, and heterogeneity of environments (Jones et al., 1994; Santos \& Aviz, 2019). One of these species is the colonial polychaete Phragmatopoma caudata Krøyer in Mörch, 1863, which created complex structures fully integrated into the landscape of algal limestone reefs (Nunes et al., 2017).
The Brazilian coastline often consists of rocky shores with highly dynamic characteristics that permanently or temporarily harbor a wide range of organisms (Abele, 1974) including colonies of $P$. caudata. This polychaete worm builds sandstone galleries by adding large amounts of individual sediment particles that are cemented with a mucoprotein secretion (Zhao et al., 2005) creating large sand reefs (Main \& Nelson, 1988; FaroniPerez, 2014). When constructing, this organism creates a biogenic microhabitat of high structural complexity that favors the increase in local 
diversity and interspecific and intraspecific interactions among individuals (Dubois et al., 2002; Noernberg et al., 2010; Ataide et al., 2014; Nunes et al., 2017).

This ample diversity is possible due to several combined factors, such as increased oxygen supply in deeper sediment cavities, availability of food resources, constant shelter (Bell, 1985; Levin et al., 1986; Borthagaray \& Carranza, 2007; Norling \& Kautsky, 2007; Ataide et al., 2014), provide a surface for larval fixation and settlement (Sepúlveda et al., 2003), and protection against desiccation and predators (Holt et al., 1998; Dias \& Paula, 2001; Ataide et al., 2014).

The use of polychaetes colonies by macrofauna has been widely registered in the world literature (Gore et al., 1978; Dias \& Paula, 2001; Sepúlveda et al., 2003; Santos-Mella et al., 2017; Velásquez et al., 2017). In Brazil, studies on the association of macrocrustaceans with biogenic galleries of the Sabellariidae family were mainly conducted for the south and southeast region (Southeastern Brazil and Rio Grande ecoregions; sensu
Spalding et al., 2007). Bosa \& Masunari (2002a, b), for example, studied Peracarida and decapods in $P$. caudata for the state of Paraná, while Pinheiro et al. (1997) and Micheletti-Flores \& Negreiros-Fransozo (1999) studied the fauna of decapods and porcelain crabs in $P$. caudata, respectively, in São Paulo. Exceptionally, the meiofauna in reefs of Sabellaria wilsoni Lana \& Gruet, 1989 was studied in the coastal region of the Amazon (Ataide et al., 2014). However, no studies have been conducted on the association of coastal fauna with polychaetes galleries in Northeastern Brazil ecoregion or the effects of these galleries on the fluctuation of biodiversity among rocky intertidal microhabitats.

Therefore, the aim of this paper was to analyze the effect of biological reefs created through associations of $P$. caudata on the local diversity of macrocrustaceans in comparison with the adjacent rocky shore microhabitat. In addition, we conducted a survey to provide further information on fauna composition for the Northeast Brazil coast.
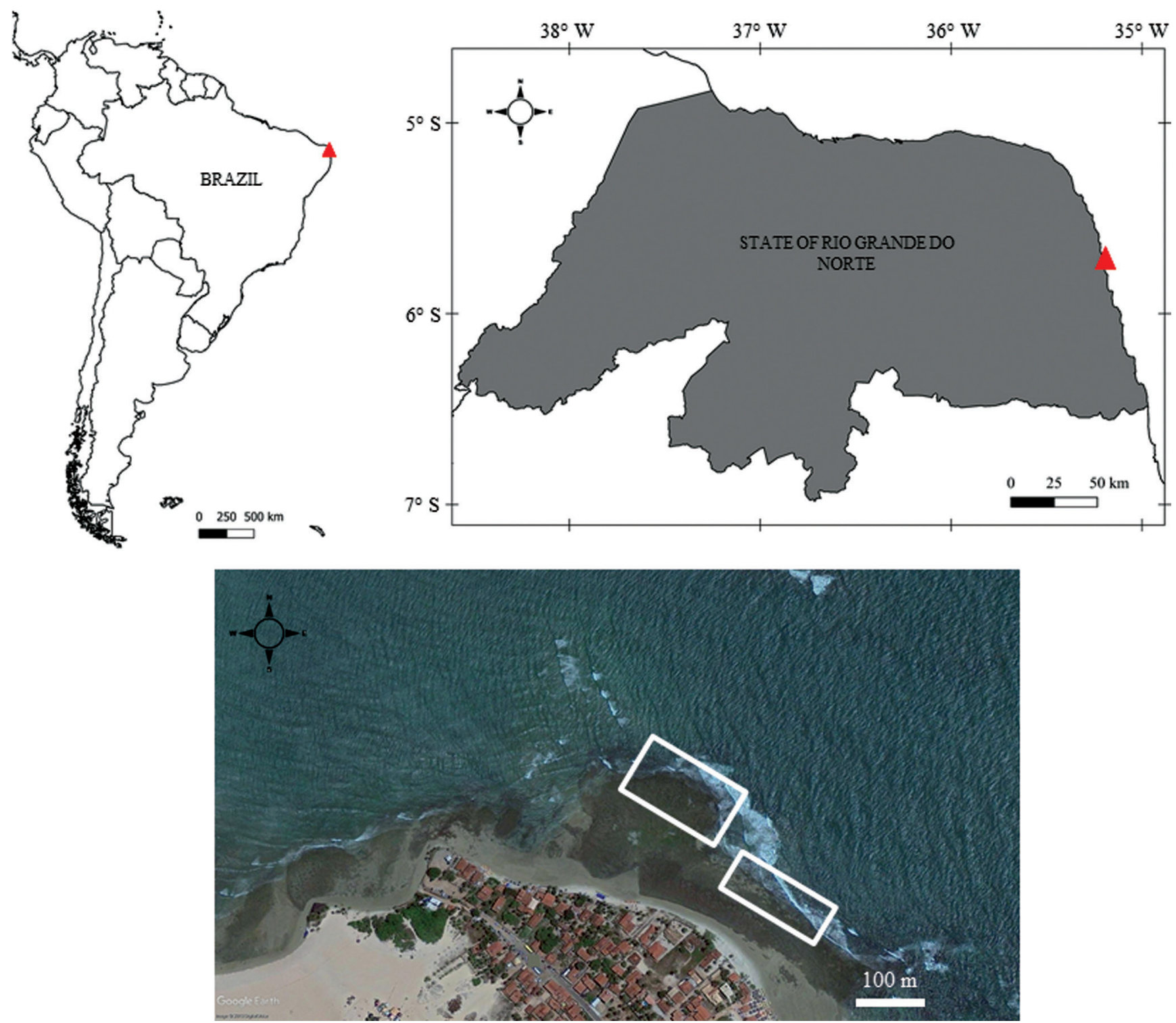

Figure 1. Study area and collection of macrocrustaceans in colonies of Phragmatopoma caudata Krøyer in Mörch (highlighted by the white square) and rocky shore in the intertidal region of Santa Rita beach, Northeast Brazil. 


\section{MATERIAL AND METHODS}

\section{Study area and data collection}

The study area is Santa Rita beach, Rio Grande do Norte, Northeast Brazil. The collections were performed on the intertidal rocky shore during the spring tide from September 2015 to August 2016. In this place, a large concentration of $P$. caudata colonies (henceforth called $\mathrm{PC}$ ) is in the portion of the coast closest to the tide line (Fig. 1). In both the polychaetes colonies and rocky intertidal (henceforth called RS), a quadrant of $10 \times 10 \mathrm{~m}$ was delimited, and the same two collectors sampled simultaneously during two-hour (capture effort) in low tide. A hammer was used to remove batches of PC colonies fixed to the rocks. All the batches and the macrocrustaceans collected were packed in sterile plastic bags, then chilled in ice, and stored in the laboratory. We also collected data on water surface temperature $\left({ }^{\circ} \mathrm{C}\right)$ using a digital thermometer and stored water samples in cryotubes to measure salinity in the laboratory using an optical refractometer.

At the laboratory, the PC batches were fragmented further to collect the animals. Finally, all animals found in both microhabitats (PC and RS) were identified to the lowest possible taxonomic level (Melo, 1996, 1999; Coelho et al., 2006; Anker, 2012; Lucatelli et al., 2012) using a stereomicroscope, counted, fixed in $70 \%$ alcohol solution, and added to the Invertebrate Collection of the Federal University of Rio Grande do Norte.

\section{Data analysis}

The species that occurred in only one sample of both environments with a single individual record were previously excluded from the analyses to ensure a more interpretable and accurate comparison. This procedure followed the original proposition of removal problematic zero records by Legendre \& Legendre (1998). We adopted this concept herein considering that a single record in one single sample might be a rare occurrence for each microhabitat analyzed. Our data also indicate though species accumulation curves (sample-based rarefaction with $95 \%$ confidence intervals; Colwell et al., 2004) that within 6-month samples diversity gather in asymptotic trend (results not shown). The following ecological indexes were estimated for the species in each microhabitat: (1) absolute abundance ( $N=$ total number of individuals), (2) relative abundance (RAb = total number of individuals per species/total number of individuals all species), (3) relative occurrence $(\mathrm{OR}=$ number of months in which the species was found/total number of months), (4) mean abundance across sampling months and its standard deviation $(X \pm S D)$. These indexes were directly compared between microhabitat to an overview of occurrence and abundance of taxa. In addition, we estimate the indices of (5) Richness, (6) Diversity $\left(\mathrm{H}^{\prime}\right)$ - Shannon-Weaver (Shannon \& Weaver, 1949), (7) Evenness (J') by the Pielou Index (Pielou, 1966), and (8) Simpson Dominance (1-D) for each microhabitat. Aforementioned index of Diversity, Evenness and Dominance had its $95 \%$ confidence intervals estimated and tested between microhabitats by means of a Bootstrap permutation procedures $(n=1000)$ (Hammer et al., 2001; Legendre \& Legendre, 2012).

Heatmap based on agglomerative hierarchical clustering were performed with biotic data (species matrix) using Bray-Curtis index and Ward method as linkage function. Prior, species matrix was fourth-root transformed and then standardized by range (Quinn \& Keough, 2002; Singh et al., 2011). This dissimilarity index and linkage function was the most efficient and provided more quality to clusters according to the Criterion Agglomeration (CA) and Cophenetic Correlation Coefficient (CPCC). The hierarchical cluster algorithm used was Bootstrap Multscale $(n=10,000)$ proposed by Shimodaira (2008). The aforementioned best clustering was determined by means of CA, CPCC and visual inspection of the dendrograms. All procedures of agglomerative hierarchical clustering and further details on CA, CPCC and Bootstrap multiscale are described in Paiva et al. (2015).

An exploratory analysis of outliers, dependence between variables, collinearity and normality was conducted with abiotic data according to the criterion and tests described by Zuur et al. (2010). A Principal Component Analysis (PCA) was conducted to evaluate data variation (Legendre \& Legendre, 2012) of environmental variables measured in each microhabitat. All principal components that cumulative explained more than $70 \%$ of data variation were inspected and significant variation were considered inspecting the loadings in modular values higher than 0.7 (Pereira et al., 2014). The data adjustment to PCA was tested according to the Kaiser-Meyer-Olkin (KMO) criterion (Kaiser, 1974). To test the difference in the environmental matrix in relation to the two microhabitats, a multivariate analysis of permutational variance (PERMANOVA) was performed (Anderson, 2014). Following, each abiotic variable was tested for normality (Shapiro \& Wilk, 1965) and homogeneity of variances by Levene's test (Sokal \& Rohlf, 1995) and then, tested median values between microhabitat by means of a MannWhitney U test (Zar, 2010).

Finally, redundancy analysis (RDA) was used to evaluate the association of species matrix in relation to the environmental variables (Legendre \& Legendre, 2012) in both microhabitats. In this procedure, we additionally performed a permutational routine $(n=9999)$ that draws the maximum correlation of environmental variables with the data of an ordination (namely, 'envfit' procedure). According to Oksanen et al. (2013) this procedure provides the evaluation of the significance of the adjusted environmental factors to the species matrix.

All the statistical analyses were performed in statistical software R (R Core Team, 2018), using the devtools packages version 1.13.6 (Wickham et al., 2018), cluster 2.0.7-1 (Maechler et al., 2018), pvclust (Suzuki \& Shimoidara, 2009), gplots 3.0.1.1 (Gregory et al., 2010), factoextra 1.0.5 (Kassambara \& Mundt, 2017), usdm 1.1-18 (Naimi et al., 2014), REdaS 0.9.3 (Maier, 2015), FactoMineR 1.41 (Le et al., 2008), vegan 2.5-4 (Oksanen et al., 2019), car 
3.0-0 (Fox \& Weisberg, 2011), and PerformanceAnalytics 1.5.2 (Peterson \& Carl, 2018). For all analyses we adopted $5 \%$ significance level (Zar, 2010).

\section{RESULTS}

A total of 3.390 macrocrustaceans were collected. Of these, 2.023 (60\%) were in P. caudata colonies and 1.367 $(40 \%)$ were found on the rocky shore. The specimens of the $P$. caudata colonies (PC) belong to 17 families and 39 species, while those in rocky shore (RS) belong to 11 families and 25 species (Table 1). All species collected in the RS were also recorded in PC; however, the PC had 6 families composed of 16 species that only occured in this microhabitat. Porcellanidae was the most abundant family for both microhabitats, with 5 species and 735 individuals (RAb $=0.363$ ) in PC, while on the RS we obtained 2 species with 339 individuals ( $R A b=0.248$ ).

In PC, the species with higher relative abundance and occurrence were Porcellanidae Pachycheles greeleyi (Rathbun, 1900) (RAb =0.173; RO = 1), followed by Megalobrachium roseum (Rathbun, 1900) (RAb $=0.048$; $\mathrm{RO}=1)$, Petrolisthes galathinus (Bosc, 1802) $(\mathrm{RAb}=0.048$; $\mathrm{RO}=1$ ), then the Diogenidae Calcinus tibicen (Herbst, 1791) $(\mathrm{RAb}=0.047 ; \mathrm{RO}=1)$, Porcellanidae Petrolisthes armatus (Gibbes, 1850) $(\mathrm{RAb}=0.047 ; \mathrm{RO}=1)$ and Pisidia brasiliensis Haig in Rodrigues da Costa, 1968 (RAb = 0.047; $\mathrm{RO}=0.83$ ). In $\mathrm{RS}$, the outstanding species were
Pachycheles greeleyi $(\mathrm{RAb}=0.272 ; \mathrm{RO}=1)$, Diogenidae C. tibicen (RAb $=0.119 ; \mathrm{RO}=0.83$ ) and Clibanarius antillensis Stimpson, 1859 (RAb $=0.088 ; \mathrm{RO}=0.83)$. Other species did not represent major trends in macrocrustacean composition.

The ecological indices of diversity, evenness and dominance showed statistical differences in the composition of macrocrustaceans among the microhabitats ( $\mathrm{n}<0.001, \mathrm{p}=999$, each comparison). The PC characterized higher Shannon's diversity index $\left(\mathrm{H}^{\prime}=3.28\right.$ bits/ individual, lower95\% $\mathrm{Cl}=3.24$, upper $95 \% \mathrm{Cl}=3.31$ ), evenness $\left(\mathrm{J}^{\prime}=0.89\right.$, lower95\%Cl $=0.88$, upper95\%Cl $\left.=0.91\right)$, and Simpson's dominance index ( $1-\mathrm{D}=0.94$, lower95\%$\mathrm{Cl}=0.93$, upper $95 \% \mathrm{Cl}=0.94$ ) in comparison to the $\mathrm{RS}$ $\left(\mathrm{H}^{\prime}=2.64\right.$ bits/individual, lower95\%Cl $=2.58$, upper95\%$\mathrm{Cl}=2.69 ; \mathrm{J}^{\prime}=0.84$, lower95\% $\mathrm{Cl}=0.82$, upper95\% $\mathrm{Cl}=0.85$ and $1-\mathrm{D}=0.88$, lower $95 \% \mathrm{Cl}=0.87$, upper95\% $\mathrm{Cl}=0.89$ ).

The heatmap by agglomerative hierarchical clustering evidenced three major species composition clusters according to microhabitat (Fig. 2). The first cluster comprise the exclusive species for PC microhabitat: P. armatus (Gibbes, 1850), P. galathinus, M. roseum, Synalpheus fritzmuelleri Coutière 1909, Pitho Iherminieri (Desbonne in Desbonne \& Schramm, 1867), Eurytium limosum (Say, 1818), Platypodiella spectabilis (Herbst, 1794), Pilumnus reticulatus Stimpson, 1860, Pilumnus dasypodus Kingsley, 1879, Neogonodactylus bredini (Manning, 1969), Palaemon northropi (Rankin, 1898), Epialtus bituberculatus $\mathrm{H}$. Milne Edwards, 1834, Macrocoeloma laevi-

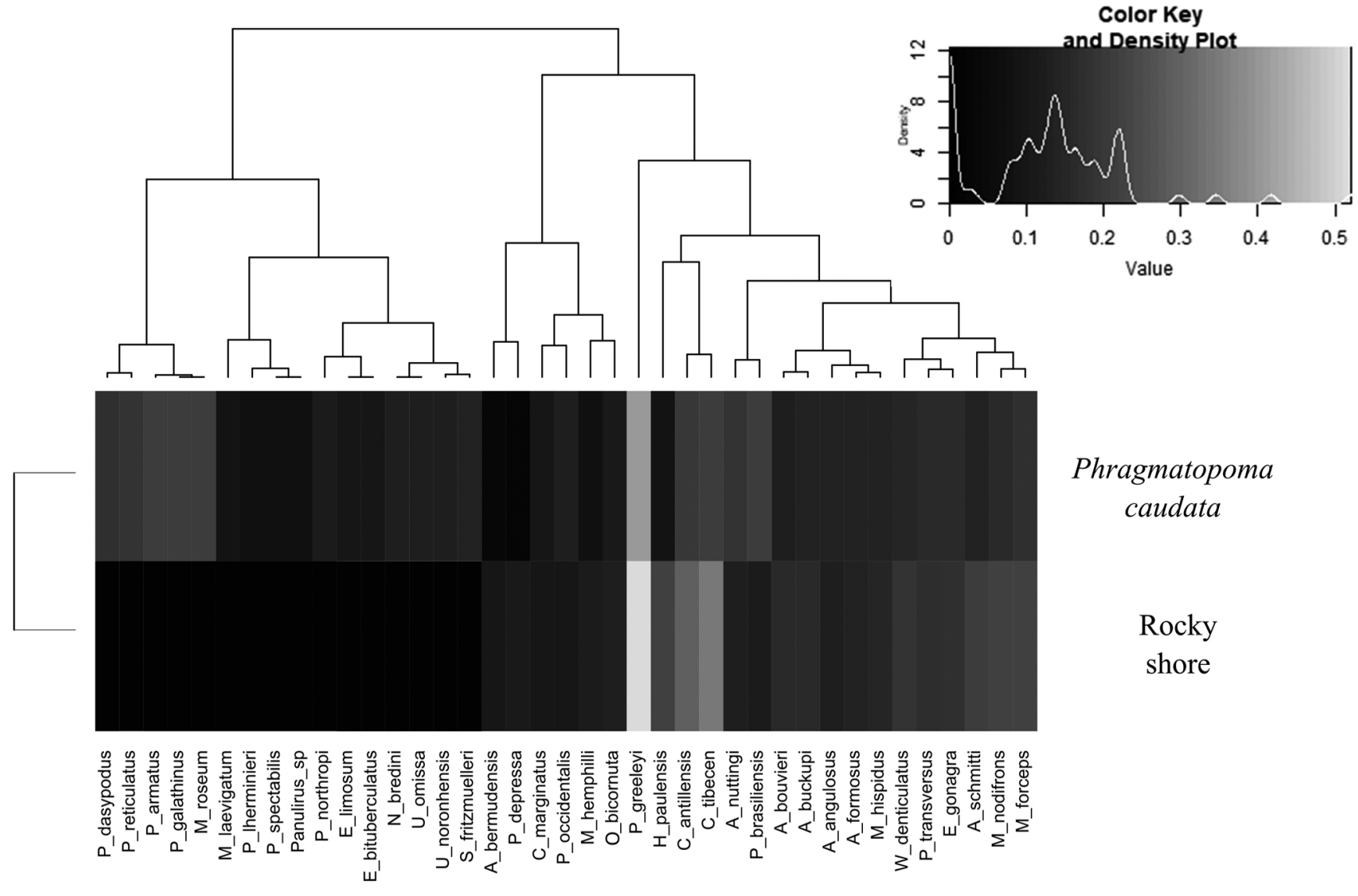

Figure 2. Heatmap estimated by relative abundance of macrocrustacean species in relation to both microhabitats: Phragmatopoma caudata Krøyer in Mörch (PC) and rocky shore (RS), in Santa Rita beach, Northeast Brazil. 
Table 1. List of species that inhabit reefs composed of Phragmatopoma caudata Kroyer in Morch (PC) and rocky shore (RS), in Praia de Santa Rita, Brazil. Absolute abundance (N); relative abundance (RAb); relative occurrence (RO); mean and standard deviation $(X \pm S D)$.

\begin{tabular}{|c|c|c|c|c|c|c|c|c|c|c|}
\hline Táxon & PC & N & RAb & RO & $X \pm S D$ & RS & N & RAb & RO & $X \pm S D$ \\
\hline \multicolumn{11}{|l|}{ Alpheidae Rafinesque, 1815} \\
\hline Alpheus angulosus McClure, $2002^{*}$ & $x$ & 41 & 0.020 & 0.83 & $3.42 \pm 2.71$ & $X$ & 25 & 0.018 & 0.75 & $2.75 \pm 2.40$ \\
\hline Alpheus bouvieri A. Milne-Edwards, 1878 & $X$ & 36 & 0.018 & 0.83 & $3 \pm 2.5$ & $X$ & 37 & 0.027 & 0.83 & $3.04 \pm 2.31$ \\
\hline Alpheus buckupi Almeida, Terossi, Araújo-Silva \& Mantelatto, 2013* & $X$ & 39 & 0.019 & 0.83 & $3.25 \pm 2.6$ & $X$ & 36 & 0.026 & 0.75 & $3.12 \pm 2.45$ \\
\hline Alpheus formosus Gibbes 1850 & $x$ & 41 & 0.020 & 1 & $3.42 \pm 2.27$ & $X$ & 29 & 0.021 & 0.58 & $2.92 \pm 2.56$ \\
\hline Alpheus nuttingi Schmitt 1924 & $X$ & 78 & 0.039 & 1 & $6.5 \pm 3.45$ & $X$ & 24 & 0.018 & 0.67 & $4.25 \pm 3.65$ \\
\hline Synalpheus fritzmuelleri Coutière 1909 & $X$ & 38 & 0.019 & 0.83 & $3.17 \pm 2.66$ & 一 & 一 & 一 & 一 & 一 \\
\hline \multicolumn{11}{|l|}{ Familia Diogenidae Ortmann 1892} \\
\hline Calcinus tibicen Herbst 1791 & $X$ & 96 & 0.047 & 1 & $8 \pm 3.36$ & $X$ & 163 & 0.119 & 0.83 & $10.79 \pm 6.38$ \\
\hline Clibanarius antillensis Stimpson, $1859^{*}$ & $x$ & 85 & 0.042 & 1 & $7.08 \pm 4.89$ & $X$ & 121 & 0.088 & 0.83 & $8.58 \pm 6.21$ \\
\hline \multicolumn{11}{|l|}{ Epialtidae MacLeay, 1838} \\
\hline Epialtus bituberculatus H. Milne Edwards, 1834 & $x$ & 22 & 0.011 & 0.67 & $1.83 \pm 1.70$ & - & - & - & - & - \\
\hline Macrocoeloma laevigatum (Stimpson, 1860) & $x$ & 16 & 0.008 & 0.83 & $1.58 \pm 1.00$ & $X$ & 一 & - & 一 & 一 \\
\hline \multicolumn{11}{|l|}{ Eriphiidae MacLeay, 1838} \\
\hline Eriphia gonagra (Fabricius, 1781) & $x$ & 53 & 0.026 & 0.83 & $4.42 \pm 2.54$ & $x$ & 46 & 0.034 & 0.92 & $4.12 \pm 2.33$ \\
\hline \multicolumn{11}{|l|}{ Gonodactylidae Giesbrecht, 1910} \\
\hline Neogonodactylus bredini (Manning, 1969) & $X$ & 33 & 0.016 & 0.92 & $2.75 \pm 1.60$ & 一 & 一 & 一 & 一 & 一 \\
\hline \multicolumn{11}{|l|}{ Grapsidae MacLeay, 1838} \\
\hline Pachygrapsus transversus (Gibbes, 1850) & $X$ & 55 & 0.027 & 1 & $4.58 \pm 2.27$ & $X$ & 41 & 0.030 & 0.92 & $4.00 \pm 2.34$ \\
\hline \multicolumn{11}{|l|}{ Menippidae Ortmann, 1893} \\
\hline Menippe nodifrons Stimpson, 1859 & $x$ & 55 & 0.027 & 1 & $4.58 \pm 2.15$ & $X$ & 68 & 0.050 & 0.92 & $5.12 \pm 2.49$ \\
\hline \multicolumn{11}{|l|}{ Mithracidae MacLeay, 1838} \\
\hline Omalacantha bicornuta (Latreille, 1825) & $x$ & 24 & 0.012 & 0.83 & $2.00 \pm 1.48$ & $X$ & 24 & 0.018 & 0.75 & $2.00 \pm 1.44$ \\
\hline Mithraculus forceps A. Milne-Edwards, $1875^{*}$ & $x$ & 64 & 0.032 & 1 & $5.33 \pm 4.01$ & $X$ & 70 & 0.051 & 0.75 & $5.58 \pm 2.26$ \\
\hline Mithrax hemphilli Rathbun, 1892 & $x$ & 14 & 0.007 & 0.67 & $1.17 \pm 1.27$ & $x$ & 19 & 0.014 & 0.62 & $1.37 \pm 1.55$ \\
\hline Mithrax hispidus (Herbst, 1790) & $X$ & 42 & 0.021 & 1 & $3.5 \pm 1.83$ & $X$ & 31 & 0.023 & 0.75 & $3.04 \pm 2.05$ \\
\hline Pitho Iherminieri (Desbonne in Desbonne \& Schramm, 1867) & $X$ & 11 & 0.005 & 0.67 & $0.92 \pm 0.79$ & 一 & 一 & - & 一 & 一 \\
\hline \multicolumn{11}{|l|}{ Palaemonidae Rafinesque, 1815} \\
\hline Palaemon northropi (Rankin, 1898)* & $x$ & 27 & 0.013 & 0.75 & $2.25 \pm 1.91$ & 一 & 一 & 一 & 一 & 一 \\
\hline \multicolumn{11}{|l|}{ Palinuridae Latreille, 1802} \\
\hline Panulirus White, 1847 & $\mathrm{X}$ & 12 & 0.006 & 0.58 & $1.00 \pm 1.04$ & 一 & - & - & - & 一 \\
\hline \multicolumn{11}{|l|}{ Panopeidae Ortmann, 1893} \\
\hline Acantholobulus bermudensis (Benedict \& Rathbun, 1891) & $x$ & 2 & 0.001 & 0.75 & $0.17 \pm 0.39$ & $x$ & 13 & 0.009 & 0.58 & $0.62 \pm 1.01$ \\
\hline Acantholobulus schmitti (Rathbun, 1930)* & $X$ & 40 & 0.020 & 0.62 & $3.33 \pm 3.47$ & $x$ & 64 & 0.047 & 0.83 & $4.33 \pm 4.00$ \\
\hline Eurytium limosum (Say, 1818) & $X$ & 25 & 0.012 & 0.75 & $2.08 \pm 1.83$ & $X$ & 25 & 0.018 & 0.83 & $2.08 \pm 1.79$ \\
\hline Hexapanopeus paulensis Rathbun, $1930^{*}$ & $x$ & 15 & 0.007 & 0.42 & $1.25 \pm 2.14$ & $x$ & 69 & 0.050 & 0.83 & $2.67 \pm 2.94$ \\
\hline Panopeus occidentalis Saussure, $1857^{*}$ & $x$ & 34 & 0.017 & 1 & $2.83 \pm 1.85$ & $x$ & 13 & 0.009 & 0.58 & $1.96 \pm 1.71$ \\
\hline \multicolumn{11}{|l|}{ Pilumnidae Samouelle, 1819} \\
\hline Pilumnus dasypodus Kingsley, 1879 & $x$ & 70 & 0.035 & 1 & $5.83 \pm 5.09$ & - & - & - & - & 一 \\
\hline Pilumnus reticulatus Stimpson, 1860 & $x$ & 73 & 0.036 & 0.92 & $6.08 \pm 4.44$ & 一 & 一 & - & 一 & 一 \\
\hline \multicolumn{11}{|l|}{ Plagusiidae Dana, 1851} \\
\hline Plagusia depressa (Fabricius, 1775) & $x$ & 1 & 0.001 & 0.08 & $0.08 \pm 0.29$ & $x$ & 17 & 0.012 & 0.83 & $0.04 \pm 0.20$ \\
\hline \multicolumn{11}{|l|}{ Portunidae Rafinesque, 1815} \\
\hline Callinectes marginatus (A. Milne-Edwards, 1861)* & $x$ & 20 & 0.010 & 0.83 & $1.67 \pm 1.31$ & $x$ & 14 & 0.010 & 0.42 & $1.17 \pm 1.46$ \\
\hline \multicolumn{11}{|l|}{ Porcellanidae Haworth, 1825} \\
\hline Megalobrachium roseum (Rathbun, 1900) & $x$ & 97 & 0.048 & 1 & $8.80 \pm 4.60$ & - & - & - & - & - \\
\hline Pachycheles greeleyi (Rathbun, 1900)* & $x$ & 351 & 0.173 & 1 & $29.25 \pm 16.08$ & $x$ & 372 & 0.272 & 1 & $30.12 \pm 32.06$ \\
\hline Petrolisthes armatus (Gibbes, 1850) & $X$ & 95 & 0.047 & 1 & $7.92 \pm 3.37$ & - & - & - & - & - \\
\hline Petrolisthes galathinus (Bosc, 1802) & $X$ & 97 & 0.048 & 1 & $8.80 \pm 2.31$ & - & - & - & - & - \\
\hline Pisidia brasiliensis Haig in Rodrigues da Costa, 1968 & $\mathrm{X}$ & 95 & 0.047 & 0.83 & $3.75 \pm 2.70$ & $X$ & 21 & 0.015 & 0.83 & $2.75 \pm 2.36$ \\
\hline Upogebiidae Borradaile, 1903 & & & & & & & & & & \\
\hline Upogebia noronhensis Fausto-Filho, 1969 & $x$ & 37 & 0.018 & 0.92 & $3.08 \pm 1.78$ & - & - & - & - & - \\
\hline Upogebia omissa Gomes Corrêa, 1968 & $\mathrm{X}$ & 33 & 0.016 & 0.83 & $2.75 \pm 1.81$ & 一 & - & 一 & - & 一 \\
\hline Xanthidae MacLeay, 1838 & & & & & & & & & & \\
\hline Platypodiella spectabilis (Herbst, 1794)* & $x$ & 12 & 0.006 & 0.83 & $1.00 \pm 0.60$ & - & - & - & - & - \\
\hline Williamstimpsonia denticulatus (White, 1848) & $x$ & 47 & 0.023 & 1 & $3.92 \pm 1.93$ & $X$ & 50 & 0.037 & 0.92 & $4.04 \pm 2.07$ \\
\hline
\end{tabular}

* Species with first occurrence in colonies of Phragmatopoma caudata Krøyer in Mörch, 1863. 
gatum (Stimpson, 1860), Upogebia noronhensis FaustoFilho, 1969, Upogebia omissa Gomes Corrêa, 1968 and Panulirus sp. White, 1847 . The second cluster comprises species with lower relative abundance in both microhabitats in comparison to the third cluster. The species Acantholobulus bermudensis (Benedict \& Rathbun, 1891), Plagusia depressa (Fabricius, 1775) and Mithrax hemphilli Rathbun, 1892 showed lower relative abundance in PC on the second cluster. In third cluster (with higher relative abundance cluster) P. greeleyi, Hexapanopeus paulensis Rathbun, 1930, C. antillensis, C. tibicen, Alpheus buckupi Almeida, Terossi, Araújo-Silva \& Mantelatto, 2013, Acantholobulus schmitti (Rathbun, 1930), Menippe nodifrons Stimpson, 1859, and Mithraculus forceps A. MilneEdwards, 1875 were lower in PC.

Principal component analysis (KMO-criterion $=0.50$; $\mathrm{PC} 1=82.7 \%$; $\mathrm{PC} 2=17.3 \%$ ) showed that the structural cavities of PC trend to lower values of water temperature (Mean $=27.47 ; 25-29.5^{\circ} \mathrm{C}$ ) and salinity (Mean = 36.17 PSU; $35-40 \mathrm{PSU})$, in comparison with the RS (Mean $=28.52^{\circ} \mathrm{C}$; $25-30.5^{\circ} \mathrm{C}$ Mean = 38.5 PSU; 35-40 PSU). The microhabitats showed fluctuations over the months and differed in relation to abiotic variables (PERMANOVA F1.22 = 4.65; $\mathrm{p}=0.024)$. However, only salinity presented a statistical difference in median values $(U=32$, Monte Carlo p-value $=0,01$ ) between microhabitats. Furthermore, Redundancy analysis revealed a temperature and salinity gradient (environmental fitting for both; $\mathrm{p}<0.01$ ) towards species that follows association with each microhabitat (Fig. 3). Consequently, species trended to group to the microhabitat composed of PC were negatively associated with increase in salinity and temperature. The porcelain crab $P$. greeleyi was the most species associated with higher values of temperature.

\section{DISCUSSION}

Macrocrustaceans associated with $P$. caudata $(\mathrm{PC})$ colonies in rocky intertidal areas are known from Caribbean to Southeast Brazil. In Northeast Brazil (Northeastern Brazil ecoregion; sensu Spalding et al., 2007) macrocrustaceans associated with PC colonies represented the highest richness in Neotropical coastal areas off South Caribbean ( $n=39$ ) as far as we known from previous investigations in this microhabitat. Species richness was average when compared to the richness found by Gore et al. (1978), who recorded 51 species of macrocrustaceans in Florida (United States of America) and higher when compared to the results found by Velásquez et al. (2017), Pinheiro et al. (1997), and Bosa \& Masunari (2002a), who recorded 27 species at Horcón Beach (Venezuela), 9 species at Ubatuba (Brazil) and 8 species at Caiobá Beach (Brazil) respectively.

Richness value founded in Northeast Brazil might be due to past connections with Caribbeans areas rather than local constraints. The mainline hypothesis is communality of species and/or the substitution of some species by others of the same trophic niche due to a past connection between these areas (Hoorn et al., 1995;

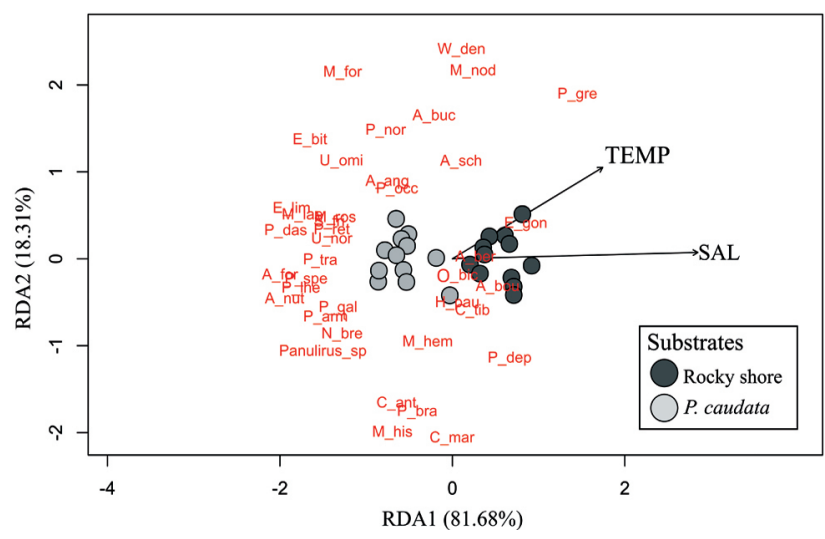

Figure 3. Redundancy Analysis triplot (RDA) addressing association of macrocrustacean species according to environmental variables (TEMP: Temperature; SAL: Salinity) on microhabitats: Phragmatopoma caudata Krøyer in Mörch and rocky shore, in Santa Rita beach, Northeast Brazil. Biotic variables: A_ang: Alpheus angulosus, A_bou: Alpheus bouvieri, A_buc: Alpheus buckupi, A_for: Alpheus formosus, A_nut: Alpheus nuttingi, S_fri: Synalpheus fritzmuelleri, C_tib: Calcinus tibicen, C_ant: Clibanarius antillensis, E_bit: Epialtus bituberculatus, M_lae: Macrocoeloma laevigatum, E_gon: Eriphia gonagra, N_bre: Neogonodactylus bredini, P_tra: Pachygrapsus transversus, M_nod: Menippe nodifrons, 0_bic: Omalacantha bicornuta, M_for: Mithraculus forceps, $M_{-}$ hem: Mithrax hemphilli, M_his: Mithrax hispidus, P_Ihe: Pitho Iherminieri, P_nor: Palaemon northropi, A_ber: Acantholobulus bermudensis, A_sch: Acantholobulus schmitti, E_lim: Eurytium limosum, H_pau: Hexapanopeus paulensis, P_occ: Panopeus occidentalis, P_das: Pilumnus dasypodus, P_ret: Pilumnus reticulatus, $\mathrm{P}$ _dep: Plagusia depressa, C_mar: Callinectes marginatus, M_ros: Megalobrachium roseum, P_gre: Pachycheles greeleyi, $\mathrm{P} \_$arm: Petrolisthes armatus, P_gal: Petrolisthes galathinus, P_bra: Pisidia brasiliensis, U_nor: Upogebia noronhensis, U_omi: Upogebia omissa, P_spe: Platypodiella spectabilis, W_den: Williamstimpsonia denticulatus.

Werding et al., 2003; Floeter et al., 2008). According to the same authors aforementioned, this past connection is currently interrupted by the freshwater barrier of the Orinoco and Amazon rivers and other several effluents in the Guyana region (established circa c. $11 \mathrm{Ma}$ ). In fact, several macrocrustaceans that co-occur at Northeast Brazil rocky intertidal shore (also in PC colonies) and Caribbean present a disjoint distribution under this freshwater barrier (Melo, 1996; Werding et al., 2003; Moraes et al., 2015) as well as other benthic species than crustacean (Alencar et al., 2017).

Also, several new records of macrocrustacean in association with P. caudata exclusively on Northeast Brazil highlight its distinct richness among off South Caribbean areas previously studied. This study presents for the first time the occurrence of Panopeidae A. schmitti, H. paulensis, Panopeus occidentalis, Alpheidae A. angulosus, A. buckupi, Portunidae C. marginatus, Diogenidae C. antillensis, Mithracidae Mithraculus forceps, Palaeomonidae $P$. northropi, Xanthidae $P$. spectabilis, and porcelain crab $P$. greeleyi in reefs of PC. Additionally, current expansion of the distribution of species associated with polychaetes colonies (within this hypothesis) is not observed to the south of Brazil (Floeter et al., 2001). Therefore, present data confronted with previous studies on this microhabitat suggests that macrocrustacean assemblage associated with $P$. caudata also might be related with the 
past connection Northeast Brazil-Caribbean hypothesis. Further inventories and diversity studies in P. caudata colonies along the Tropical Atlantic Realm (sensu Spalding et al., 2007) are encouraged to build baseline information on macrocrustacean composition for a proper investigation on this hypothesis in near future.

It is fairly recognized that habitat structure may affect abundance, density, and diversity in ecosystems (Grinnell, 1917; Gibbons, 1988; Beck, 2000; Schiel, 2004). Habitat structure is often used as a physical surrogate aspect in biodiversity studies since this concept depends on the measured resolution according to species under study i.e., the relative abundance of different structural features (heterogeneity) and the physical architecture of a habitat (complexity) (McCoy \& Bell, 1991; McArthur et al., 2010). Habitat structure of PC colonies might be the main attribute to promote a high diversity of macrocrustaceans compared to RS. Habitats created by living organisms, in particular, by polychaetes, on intertidal shores are structurally more complex than the surrounding rock surface, attracting a wide range of invertebrates (Bosa \& Masunari, 2002a; Monteiro et al., 2002; Chapman et al., 2012).

One of the consequences of increasing the complexity of the ecosystem is the increase in the availability of microhabitats, providing shelter and/or refuge for the associated fauna (Whalen et al., 2016). For example, increasing structural complexity can relieve environmental stresses during low tide, as intertidal organisms need to be protected from displacement in beds of mussels (Seed, 1996) and/or tufts of Fucus that provide shelter for a variety of macroinvertebrates (Thompson et al., 1996). In that way, one example of heterogeneous biological microhabitats is macroalgae, which as more structurally complex as it is, presented higher relative abundance of shelter (heterogeneity) and diverse sets of invertebrates (Gee \&Warwick, 1994; Chemello \& Milazzo, 2002). The colonies present high complexity through the aggregation of polychaetes tubes, and in the course of time they can increase their heterogeneity due to the wear of the microhabitat by the action of sea water or by the action of excavator animals, while the RS is mostly heterogeneous (Fig. 4).
Polychaetes biogenic microhabitats are used as shelter by groups of vertebrates and invertebrates (Bell, 1985; Levin et al., 1986; Borthagaray \& Carranza, 2007; Norling \& Kautsky, 2007; Ataide et al., 2014). Besides that, polychaetes colonies provide food because they perform bioturbation to work matter that enters through the action of waves, and organic matter from decomposed organisms (Pinheiro et al., 1997). Dominance of porcelain crabs is probably due to the availability of microhabitats for shelter and because they occupy the same trophic level as polychaetes, feeding on plankton organisms and organic matter inside the colonies (Micheletti-Flores \& Negreiros-Fransozo, 1999; Bosa \& Masunari, 2002a; Velásquez et al., 2017). All species of this family such as $P$. greeleyi, P. brasiliensis and three other exclusive species in this particular microhabitat, $M$. roseum, $P$. galathinus, and $P$. armatus benefit from this condition. Only $P$. greeleyi has not been previously reported in association with polychaetes but some studies have already confirmed species of the genus Pachycheles as the most abundant in Phragmatopoma reefs or another reefs of Sabellariidae worms (Gore et al., 1978; Pinheiro et al., 1997; MichelettiFlores \& Negreiros-Fransozo, 1999).

Species that usually occupy habitats other than polychaetes colonies indicate that this microhabitat also can be used as refugium for a certain population of organisms in periods of unfavorable conditions (Selwood \& Zimmer, 2020). The species with smaller abundances, such as S. fritzmuelleri, P. Iherminieri, E. limosum, P. spectabilis, P. dasypodus, N. bredini, P. northropi, E. bituberculatus, M. laevigatum, U. noronhensis, U. omissa and Panulirus sp., prefer macroalgae banks, coral reefs, sponge banks and near the mangroves (Marx \& Herrnkind, 1985; Kneib \& Weeks, 1990; Candisani et al., 2001; Melo \& Veloso, 2005; Devries, 2012; Cházaro-Olvera \& Vázquez-Lopez, 2014; Moraes et al., 2015; Paiva Barros-Alves et al., 2019). The predilection for these complex habitats and the location of colonies closest to the subtidal region suggests that the tidal movement may be helping the action of the PC as a temporary refugium for these species. As an example of the transport of species to the colonies through the tide, we observed the occasional occurrence of mac-
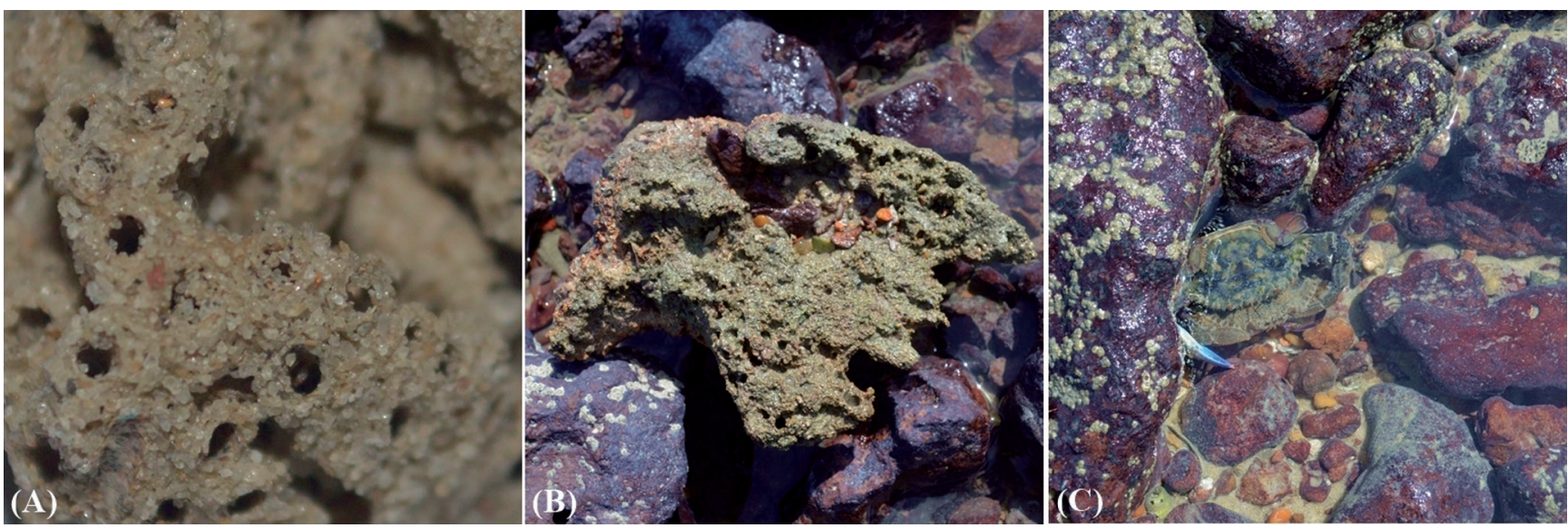

Figure 4. Complex microhabitat in Phragmatopoma caudata Krøyer in Mörch (A, B) and heterogeneous microhabitat in the rocky shore (C), in the intertidal region of Santa Rita beach, Northeast Brazil. 
roalgae, and mangrove leaves attached to the colonies. As recorded by Bosa \& Masunari (2002b) individuals occupying the polychaetes microhabitat were mostly juveniles. In fact, we also observed this in present study with most of the species that prefer other microhabitats aforementioned. In that way, we are assuming that in the period of rising tides, this juveniles initially have access to the structural complexity of the PC (closest to lower tide line) than to the RS (upper tide line and occasionally flanked on PC) (Fig. 1), and can take refugium when facing threats to their survival, such as inter- and intra-species interactions (e.g., predation and competition) or regular abiotic pressures, such as high daytime temperatures or salinities (Selwood \& Zimmer, 2020).

Water temperature is a key factor influencing physiological performance and organism distribution in intertidal microhabitats (Bertness, 1981; Somero, 2002; Snyder et al., 2001; Gilman et al., 2006). For intertidal species upper zonation limits are usually associated with body desiccation and thermal regulation (due to more body air exposure) while wave break zones are less stressful to thermoregulation (Helmuth, 1999; Helmuth \& Hoffman, 2001). According to the aforementioned authors, during body air exposure heat flux is determined by the animal movement and interactions with structural elements of the habitat while submerged an ectotherm likely has a temperature similar to water surrounding it. Then, microhabitat preferences (and herein its environmental factors) are crucial to ectothermic organisms, such as macrocrustaceans.

In the present study, water temperatures were similar in mean values with discrete variation towards RS microhabitat. However, salinity variation was statistically different among the microhabitats with higher value in RS. Therefore, the abiotic conditions analyzed showed that the RS has proven to be more selective in relation to the diversity and evenness of species capable of living in it, requiring physiological mechanisms to tolerate a wider range of physical conditions than those living in PC (Newell, 1976; Helmuth \& Hoffmann, 2001; Szathmary et al., 2009). The high degree of evaporation in RS at low tide, promotes microhabitats with higher range of salinity and low water movement (Garrity, 1984), causing less oxygen dissolution, as well as less suspended matter that could potentially serve as food (Almeida, 2008). Meanwhile, the PC offers several advantages for organisms residing in this microhabitat (Bosa \& Masunari, 2002a; Velásquez et al., 2017), including environmental stability and less stressful conditions that favor the occurrence of a relevant species richness.

Another notable species is the hermit crab C. tibicen, which also had a high relative abundance in both microhabitats. The hermit crabs require gastropod shells for protection (Hazlett, 1981) in a symbiosis (metabiosis). Despite other major species discussed previously, hermit crabs preferred rocky shore. Large cracks of the RS provided wider movement and some refuge during the low tide period. In addition, gastropod shells in metabiosis prevent (at some extent) desiccation and thermoregulation.
However, the availability of shells is not the only factor that determines the number of hermits in an area, Vance (1972) considered that a complex environment, with several hiding places, also provides the animal with greater protection. Vale et al. (2017) studied two sister taxa of hermit crab in a coastal lagoon with temporal connection to mangrove and intertidal rocky coast serving as temporary refuge and recruit area. The aforementioned authors found that intra- and interspecific competition appears to be regulated by differential shell preference between species and in their sizes classes. Therefore, we assume that the dominance of this species on the RS is caused by the high availability of gastropod shells (pers. comm., Lane-Medeiros, L.) and competition for this resource has imposed on some individuals of smaller average size the occupation of other microhabitats, such as PC, in search of additional protection in worm tubes, different forms of crevices or other types of shells. The literature confirms the occurrence of this species in the RS and polychaetes reefs (Almeida et al., 2008; Velásquez et al., 2017).

Finally, this study is the first in northeastern Brazil ecoregion to analyze the composition and diversity of macrocrustaceans in polychaetes colonies. Data were compared to rocky shores of the same local area to enhance interpretation of the results. Since richness found in RS was totally recorded on PC, we could propose scenarios to the distinct richness in PC. Additionally, according to previous known habitat information for majority species we could state that $P$. caudata colonies might be a refuge/shelter microhabitat for aquatic fauna temporarily. Recommendations for further investigations include depict the ontogenetic or size classes associations between species commonly found in this microhabitat. Also, we recommend additional studies with direct measure on heterogeneity and complexity, including recent proposals of fractal dimensions variables for rocky intertidal zones (Meager et al., 2011).

Information provided herein is the baseline for future research on the biology and ecology of the species found in this microhabitat. We also increased knowledge about the basic abiotic conditions that this microhabitat provides for the fauna and extended the worldwide list of species that occur in PC microhabitat. From all new reports of this manuscript, we highlight the first record of association with porcelain crab $P$. greeleyi and $P$. caudata colonies. This porcelain crab is endemic to the Brazilian coast and was dominant in both microhabitats. Therefore, identification of habitat structure that provide shelter and refugium for macrocrustacean biodiversity is strategic for conservation managers to prioritize the preservation of this microhabitat and subsequent species. Such species constitute important trophic chain position at other ecosystems (such as mangroves), fishery resources that permanently or temporarily inhabit this microhabitat (such as Panulirus sp.) or even some level of endemism, as observed for $P$. greeleyi, the only Porcellanidae endemic species below Caribbean-West Indian region (Werding et al., 2003). 


\section{ACKNOWLEDGMENTS}

The authors are thankful to the Conselho Nacional de Desenvolvimento Científico e Tecnológico (CNPq) and Coordenação de Aperfeiçoamento de Pessoal de Nível Superior (CAPES) that supported this work in part under scholarships to L.L.-M. [131915/2020-7] and M.A.L.R. [88882.375467/2019-01], respectively.

\section{AUTHORS' CONTRIBUTIONS}

Conceived and designed the project: L.L.-M., M.A.L.R., F.A.M.F. Collected field samples and species identification: M.A.L.R. Analyzed the data: L.L.-M., C.T.P.G., C.E.R.D.A. Wrote the paper: L.L.-M., C.T.P.G., M.A.L.R., C.E.R.D.A. F.A.M.F. All authors read and approved the final version of the manuscript.

\section{REFERENCES}

Abele, L.G. 1974. Species diversity of decapod crustaceans in marine habitats. Ecology, 55(1): 156-161.

Alencar, C.E.R.D.; Vale, V.F.; Moraes, S.A.S.N.; Nascimento Araújo, P.V. \& Freire, F.A.M. 2017. New record of the Six-holed Keyhole Urchin, Leodia sexiesperforata (Leske, 1778) (Clypeasteroida, Mellitidae), from the Brazilian coast, with an updated distribution map. Checklist, 13(5): 597-603.

Almeida, A.O.; Bezerra, L.E.; Souza-Filho, J.F.; Almeida, S.M.; Albuquerque, D.L. \& Coelho P.A. 2008. Decapod and stomatopod crustaceans from Santo Aleixo Island, state of Pernambuco, Brazil. Nauplius, 16: 23-41.

Almeida, V.F. 2008. Importância dos costões rochosos nos ecossistemas costeiros. Cadernos de ecologia aquática, 3(2): 19-32.

Anderson, M.J. 2014. Permutational multivariate analysis of variance (PERMANOVA). In: Wiley statsref: statistics reference online. John Willey and Sons. p. 1-15.

Anker, A. 2012. Revision of the western Atlantic members of the Alpheus armillatus H. Milne Edwards, 1837 species complex (Decapoda, Alpheidae), with description of seven new species. Zootaxa, 3386: 1-109.

Ataide, M.B.; Venekey, V.; Rosa-Filho, J.S. \& Santos, P.J.P. 2014. Sandy reefs of Sabellaria wilsoni (Polychaeta: Sabellariidae) as ecosystem engineers for meiofauna in the Amazon coastal region, Brazil. Marine Biodiversity, 44(3): 403-413

Beck, M.W. 2000. Separating the elements of habitat structure: independent effects of habitat complexity and structural components on rocky intertidal gastropods. Journal of experimental marine biology and ecology, 249: 29-49.

Bell, S.S. 1985. Habitat complexity of polychaete tube-caps: Influence of architecture on dynamics of a meioepibenthic assemblage. Journal of Marine Research, 43(3): 647-671.

Bertness, M.D. 1981. Predation, physical stress, and the organization of a tropical rocky intertidal hermit crab community. Ecology, 62(2): 411-425.

Borthagaray, A.I. \& Carranza, A. 2007. Mussels as ecosystem engineers: their contribution to species richness in a rock littoral community. Acta Oecologica, 31(3): 243-250.

Bosa, C.R. \& Masunari, S. 2002a. Crustáceos decápodos associados aos bancos de Phragmatopoma caudata (Krøyer) (Polychaeta, Sabellariidae) na Praia de Caiobá, Matinhos, Paraná. Revista Brasileira de Zoologia, 19(Suppl. 1): 117-133.
Bosa, C.R. \& Masunari, S. 2002b. Peracáridos associados aos bancos de Phragmatopoma caudata (Krøyer) (Polychaeta, Sabellariidae) na Praia de Caiobá, Matinhos, Paraná. Revista Brasileira de Zoologia, 19(Suppl. 1): 135-147.

Candisani, L.C.; Sumida, P.Y.G. \& Pires-Vanin, A.M.S. 2001. Burrow morphology and mating behaviour of the thalassinidean shrimp Upogebia noronhensis. Journal of the Marine Biological Association of the United Kingdom, 81(5): 799-803.

Chapman, N.D.; Moore, C.G.; Harries, D.B. \& Lyndon, A.R. 2012. The community associated with biogenic reefs formed by the polychaete, Serpula vermicularis. Marine Biological Association of the United Kingdom. Journal of the Marine Biological Association of the United Kingdom, 92(4): 679.

Cházaro-Olvera, S. \& Vázquez-López, H. 2014. Association of Synalpheus (Crustacea, Decapoda, Alpheidae) with the sponges from Parque Marino Nacional Sistema Arrecifal Veracruzano, SW Gulf of Mexico. Biología Ciencia y Tecnología, 7.

Chemello, R. \& Milazzo, M. 2002. Effect of algal architecture on associated fauna: some evidence from phytal molluscs. Marine biology, 140(5): 981-990.

Coelho, P.A.; De Almeida, A.0.; De Souza-Filho, J.F.; Bezerra, L.E.A. \& Giraldes, B.W. 2006. Diversity and distribution of the marine and estuarine shrimps (Dendrobranchiata, Stenopodidea and Caridea) from North and Northeast Brazil. Zootaxa, 1221: 41-62.

Colwell, R.K.; Mao, C.X. \& Chang, J. 2004. Interpolating, extrapolating, and comparing incidence-based species accumulation curves. Ecology, 85(10): 2717-2727.

Devries, M.S. 2012. The feeding morphology and ecology of stomatopod crustaceans (Doctoral dissertation) UC Berkeley.

Dias, A.S.\& Paula, J. 2001. Associated fauna of Sabellaria alveolata colonies on the central coast of Portugal. Journal of the Marine Biological Association of the United Kingdom, 81(1): 169-170.

Dubois, S.; Retière, C. \& Olivier, F. 2002. Biodiversity associated with Sabellaria alveolata (Polychaeta: Sabellariidae) reefs: effects of human disturbances. Journal of the Marine Biological Association of the United Kingdom, 82(5): 817-826.

Faroni-Perez, L. 2014. Seasonal variation in recruitment of Phragmatopoma caudata (Polychaeta, Sabellariidae) in the southeast coast of Brazil: validation of a methodology for categorizing age classes. Iheringia Série Zoologia, 104: 5-13.

Floeter, S.R.; Guimarães, R.Z.; Rocha, L.A.; Ferreira, C.E.L.; Rangel, C.A. \& Gasparini, J.L. 2001. Geographic variation in reef-fish assemblages along the Brazilian coast. Global Ecology and Biogeography, 10(4): 423-431.

Floeter, S.R.; Rocha, L.A.; Robertson, D.R.; Joyeux, J.C.; Smith-Vaniz, W.F.; Wirtz, P.; Edwards, A.J.; Barreiros, J.P.; Ferreira, C.E.L.; Gasparini, J.L.; Brito, A.; Falcón, J.M.; Bowen, B.W. \& Bernardi, G. 2008. Atlantic reef fish biogeography and evolution. Journal of Biogeography, 35: 22-47.

Fox, J. \& Weisberg, S. 2011. An R companion to applied regression. 2.ed. Thousand Oaks CA., Sage. Disponível em : https://socialsciences. mcmaster.ca/jfox/Books/Companion-2E/index.html.

Garrity, S.D. 1984. Some adaptations of gastropods to physical stress on a tropical rocky shore. Ecology, 65(2): 559-574.

Gee, J.M. \& Warwick, R.M. 1994. Metazoan community structure in relation to the fractal dimensions of marine macroalgae. Marine Ecology Progress Series, 103(1-2): 141-150.

Gibbons, M.J. 1988. The impact of sediment accumulations, relative habitat complexity and elevation on rocky shore meiofauna. Journal of experimental marine biology and ecology, 122(3): 225-241.

Gilman, S.E.; Wethey, D.S. \& Helmuth, B. 2006. Variation in the sensitivity of organismal body temperature to climate change over local and geographic scales. Proceedings of the National Academy of Sciences, 103(25): 9560-9565. 
Gore, R.H.; Scolto, L.E. \& Becker, L.J. 1978. Community composition, stability, and trophic partitioning in decapod crustaceans inhabiting some subtropical sabellariid worm reefs. Bulletin of Marine Science, 28: 221-248.

Gregory, R.W.; Bolker, B.; Bonebakker, L.; Gentleman, R.; Liaw, W.H.A.; Lumley, T. \& Maechler, M. 2010. gplots: various $R$ Programming tools for plotting data. $R$ package version 2.8.0. http://CRAN.R-project.org/ package $=$ gplots.

Grinnell, J. 1917. The niche relationships of the California Thrasher. The Auk, 34: 427-433.

Hammer, Ø.; Harper, D.A.T. \& Ryan, P.D. 2001. PAST: Paleontological statistics software package for education and data analysis. Palaeontologia Electronica, 4: 1-9.

Hazlett, B.A. 1981. The behavioral ecology of hermit crabs. Annual Review of Ecology and Systematics, 12: 1-22.

Helmuth, B. 1999. Thermal biology of rocky intertidal mussels: quantifying body temperatures using climatological data. Ecology, 80: 15-34.

Helmuth, B.S. \& Hofmann, G. 2001. Microhabitats, thermal heterogeneity, and patterns of physiological stress in the rocky intertidal zone. The Biological Bulletin, 201(3): 374-384.

Holt, T.J.; Rees, E.I.; Hawkins, S.J. \& Seed, R. 1998. Biogenic reefs. An overview of dynamic and sensitivity characteristics for conservation management of marine SACs. Oban, Scotland, Scottish Association of Marine Sciences/UK Marine SACs Project. v. 9, 170p.

Hoorn, C.; Guerrero, J.; Sarmiento, G.A. \& Lorente, M.A. 1995. Andean tectonics as a cause for changing drainage patterns in Miocene northern South America. Geology, 23(3): 237-240.

Jones, C.G.; Lawton, J.H. \& Shachak, M. 1994. Organisms as ecosystem engineers. Oikos, 69: 373-386.

Kaiser, H.F. 1974. An index of factorial simplicity. Psychometrika, 39: 31-36.

Kassambara, A. \& Mundt, F. 2017. factoextra: extract and visualize the results of multivariate data analyses. $R$ package version 1.0.5. https://CRAN.Rproject.org/package=factoextra.

Kneib, R.T. \& Weeks, C.A. 1990. Intertidal distribution and feeding habits of the mud crab, Eurytium limosum. Estuaries, 13(4): 462-468.

Le, S.; Josse, J. \& Husson, F. 2008. FactoMineR: An R package for multivariate analysis. Journal of Statistical Software, 25: 1-18.

Legendre, P. \& Legendre, L. 1998. Numerical Ecology. 2.ed. Elsevier. 852p.

Legendre, P. \& Legendre, L. 2012. Numerical Ecology. 3.ed. Elsevier. 990p.

Levin, L.A.; Demaster, D.J.; Mccann, L.D. \& Thomas, C.L. 1986. Effects of giant protozoans and (class: Xenophyophorea) on deep-seamount benthos. Marine Ecology Progress Series, 29: 99-104.

Lucatelli, D.; Bezerra, L.E.; dos Santos, P.J. \& Coelho, P.A. 2012. Checklist of Stomatopoda (Malacostraca: Hoplocarida) deposited in the MOUFPE collection, with a new record from Brazil. Nauplius, 20(2): 257-293.

Maechler, M.; Rousseeuw, P.; Struyf, A.; Hubert, M. \& Hornik, K. 2018. Cluster: cluster analysis basics and extensions. R package version 2.0.7-1.

Maier, M.J. 2015. Companion Package to the Book "R: Einführung durch angewandte Statistik". R package version 0.9.3. http://CRAN.R-project. org/package $=$ REdaS.

Main, M.B. \& Nelson, W.G. 1988. Sedimentary characteristics of sabellariid worm reefs (Phragmatopoma lapidosa Kinberg). Estuarine, Coastal and ShelfScience, 26(1): 105-109.

Marx, J.M. \& Herrnkind, W.F. 1985. Macroalgae (Rhodophyta: Laurencia spp.) as habitat for young juvenile spiny lobsters, Panulirus argus. Bulletin of Marine Science, 36(3): 423-431.

McArthur, M.A.; Brooke, B.P.; Przeslawski, R.; Ryan, D. A.; Lucieer, V.L.; Nichol, S.; McCallum, A.W.; Mellin, C.; Cresswell, I.D. \& Radke, L.C. 2010. On the use of abiotic surrogates to describe marine benthic biodiversity. Estuarine, Coastal and Shelf Science, 88: 21-32.
McCoy, E.D. \& Bell, S.S. 1991. Habitat structure: the evolution and diversification of a complex topic. In: Bell, S.S.; McCoy, E.D. \& Mushinsky, H.R. (Eds.). Habitat structure, the physical arrangement of objects in space. New York, Chapman \& Hall. p. 3-27.

Meager, J.J.; Schlacher, T.A. \& Green, M. 2011. Topographic complexity and landscape temperature patterns create a dynamic habitat structure on a rocky intertidal shore. Marine Ecology Progress Series, 428: 1-12.

Melo, G.A.S. 1996. Manual de Identificação dos Brachyura (Caranguejos e Siris) do Litoral Brasileiro. São Paulo, FAPESP.

Melo, G.A.S. 1999. Manual de Identificação dos Crustacea Decapoda do Litoral Brasileiro. São Paulo, FAPESP.

Melo, G.A. \& Veloso, V.G. 2005. The brachyura (Crustacea, Decapoda) of the coast of the state of Paraíba Brazil, collected by Project Algas. Revista brasileira de Zoologia, 22(3): 795-805.

Micheletti-Flores, C.V. \& Negreiros-Fransozo, M.L. 1999. Porcellanid crabs (Crustacea, Decapoda) inhabiting sand reefs built by Phragmatopoma lapidosa (Polychaeta, Sabellariidae) at Paranapuã Beach, São Vicente, SP, Brazil. Brazilian Journal of Biology, 59: 59-62.

Monteiro, S.M.; Chapman, M.G. \& Underwood, A.J. 2002. Patches of the ascidian Pyura stolonifera (Heller, 1878): structure of habitat and associated intertidal assemblages. Journal of Experimental Marine Biology and Ecology, 270(2): 171-189.

Moraes, S.A.S.N.; Alencar, C.E.R.D.; Thomsen, E. \& Freire, F.A.M. 2015. New records of the hairy crab Pilumnus dasypodus (Decapoda, Brachyura, Pilumnidae) in northeastern Brazil. Check List, 11(2): 1563.

Naimi, B.; Hamm, N.A.; Groen, T.A.; Skidmore, A.K. \& Toxopeus, A.G. 2014. "Where is positional uncertainty a problem for species distribution modelling". Ecography, 37: 191-203.

Newell, R.C. 1976. Adaptations to intertidal life. In: Newell, R.C. (Ed.). Adaptations to environment. London, Butterworths.

Noernberg, M.A.; Fournier, J.; Dubois, S. \& Populus, J. 2010. Using airborne laser altimetry to estimate Sabellaria alveolata (Polychaeta: Sabellariidae) reefs volume in tidal flat environments. Estuarine, Coastal and Shelf Science, 90: 93-102.

Norling, P. \& Kautsky, N. 2007. Structural and functional effects of Mytilus edulis on diversity of associated species and ecosystem functioning. Marine Ecology Progress Series, 351: 163-175.

Nunes, F.L.;VanWormhoudt, A.;Faroni-Perez,L.\&Fournier,J.2017.Phylogeography of the reef-building polychaetes of the genus Phragmatopoma in the western Atlantic Region. Journal of Biogeography, 44(7): 1612-1625.

Oksanen, J.; Blanchet, F.G.; Friendly, M.; Kindt, R.; Legendre, P.; Mcglinn, D.; Minchin, P.R.; O'hara, R.B.; Simpson, G.L.; Solymos, P.; Stevens, M.H.H.; Szoecs, E. \& Wagner, H. 2019. vegan: Community Ecology Package. R package version 2.5-4. https://CRAN.R-project.org/package=vegan.

Oksanen, J.; Blanchet, F.G.; Kindt, R.; Legendre, P.; Minchin, P.R.; O'Hara, R.B.; Simpson, G.L.; Solymos, P.; Stevens, M.H.H. \& Wagner, H. 2013. Vegan: community ecology package. R package Version 2: 1-17.

Paiva Barros-Alves, S.; Tupy, G.S.; Almeida, A.S.; Santos, M.S. \& Alves, D.F.R. 2019. Reproductive biology of the shrimp Palaemon northropi (Rankin, 1898) (Caridea: Palaemonidae) from an estuary in the Brazilian northeastern. Scientia Plena, 15(9): 1-12.

Paiva, M.I.G.; Mendes, L.F.; Lins-Oliveira, J.E.; Alencar, C.E.R.D. \& Torquato, F.O. 2015. Temporal and spatial patterns on the settlement of reef fish larvae in a South Atlantic reef, Bahia, Brazil. Pan-American Journal of Aquatic Sciences, 10: 19-28.

Pereira, R.T.; Teixeira, G.M.; Bertini, G.; de Lima, P.A.; Alencar, C.E. \& Fransozo, V. 2014. Environmental factors influencing the distribution of three species within the genus Persephona Leach, 1817 (Crustacea, Decapoda, Leucosiidae) in two regions on the northern coast of São Paulo State, Brazil. Latin American Journal of Aquatic Research, 42(2): 307-321. 
Peterson, B.G. \& Carl, P. 2018. Performance analytics: econometric tools for performance and risk analysis. R package version 1.5.2. https://CRAN.Rproject.org/package $=$ PerformanceAnalytics.

Pielou, E.C. 1966. The measurement of diversity in different types of biological collections. Journal of theoretical biology, 13: 131-144.

Pinheiro, M.A.A.; Bertini, G.; Fernandes-Góes, L.G. \& Fransozo, A. 1997. Decapod crustaceans associated to sand reefs of Phragmatopoma lapidosa Kinberg, 1867 (Polychaeta, Sabellariidae) at Praia Grande, Ubatuba, SP, Brazil. Nauplius, 5(2): 77-83.

Quinn, G. \& Keough, M. 2002. Experimental design and data analysis for biologists. Cambridge, Cambridge University Press. 509p.

$\mathrm{R}$ Core Team. 2018. R: A language and environment for statistical computing. Vienna, R Foundation for Statistical Computing. https://www.R-project. org.

Santos, T.M.T. \& Aviz, D. 2019. Macrobenthic fauna associated with Diopatra cuprea (Onuphidae: Polychaeta) tubes on a macrotidal sandy beach of the Brazilian Amazon Coast. Journal of the Marine Biological Association of the United Kingdom, 99(4): 751-759.

Santos-Mella, F.; Contreras-Puigbó, A.; Pugibet, E. \& Rivas, D.V. 2017. Ecología y biodiversidad de un arrecife formado por Phragmatopoma caudata Krøyer in Mörch (Canalipalpata: Sabellariidae) en República Dominicana. Novitates Caribaea, 11: 69-78.

Schiel, D.R. 2004. The structure and replenishment of rocky shore intertidal communities and biogeographic comparisons. Journal of Experimental Marine Biology and Ecology, 300(1-2): 309-342.

Seed, R. 1996. Patterns of biodiversity in the macro invertebrate fauna associated with mussel patches on rocky shores. Journal of the Marine Biological Association of the United Kingdom, 76: 203-210.

Selwood, K.E. \& Zimmer, H.C. 2020. Refuges for biodiversity conservation: A review of the evidence. Biological Conservation, 245 (108502): 1-9.

Sepúlveda, R.D.; Moreno, R.A. \& Carrasco, F.D. 2003. Diversidad de macroinvertebrados asociados a arrecífes de Phragmatopoma moerchi Kinberg, 1867 (Polychaeta: Sabellariidae) en el intermareal rocoso de Cocholgüe, Chile. Gayana, 67: 45-54.

Shannon, C.E. \& Weaver, W. 1949. The mathematical theory of communication. Urbana, University of Illinois Press. 117p.

Shapiro, S.S. \& Wilk, M.B. 1965. An analysis of variance test for normality (complete samples). Biometrika, 52: 591-611.

Shimodaira, H. 2008. Testing regions with nonsmooth boundaries via multiscale bootstrap. Journal of Statistical Planning and Inference, 138(5): 1227-1241.

Singh, W.; Hjorleifsson, E. \& Stefansson, G. 2011. Robustness of fish assemblages derived from three hierarchical agglomerative clustering algorithms performed on Icelandic groundfish survey data. ICES Journal of Marine Science, 68(1): 189-200.

Snyder, M.J.; Girvetz, E. \& Mulder, E.P. 2001. Induction of marine mollusc stress proteins by chemical or physical stress. Archives of environmental contamination and toxicology, 41:22-29.
Sokal, R.R. \& Rohlf, F.K. 1995. Biometry: The Principles and Practice of Statistics in Biological Research. 3.ed. New York, W.H. Freeman and Company.

Somero, G.N. 2002. Thermal physiology and vertical zonation of intertidal animals: optima, limits, and costs of living. Integrative and comparative biology, 42(4): 780-789.

Spalding, M.D.; Fox, H.E.; Allen, G.R.; Davidson, N.; Ferdana, Z.A.; Finlayson, M.; Halpern, B.S.; Jorge, M.A.; Lombana, A.; Lourie, S.A.; Martin, K.D.; Macmanus, E.; Molnar, J.; Recchia, C.A. \& Robertson, J. 2007. Marine ecoregions of the world: a bioregionalization of coastal and shelf areas. BioScience, 57(7): 573-583.

Suzuki, R. \& Shimodaira, H. 2009. Pvclust: Hierarchical clustering with p-values via multiscale bootstrap resampling. $R$ package version 1.2-1. http:// www.is.titech.ac.jp/shimo/prog/pvclust.

Szathmary, P.L.; Helmuth, B. \& Wethey, D.S. 2009. Climate change in the rocky intertidal zone: predicting and measuring the body temperature of a keystone predator. Marine Ecology Progress Series, 374: 43-56.

Thompson, R.C.; Wilson, B.J.; Tobin, M.L.; Hill, A.S. \& Hawkins, S.J. 1996. Biologically generated habitat provision and diversity of rocky shore organisms at a hierarchy of spatial scales. Journal of Experimental Marine Biology and Ecology, 202: 73-84.

Vale, V.F.; Moraes, S.A.; Brito, V.L.; Alencar, C.E.R.D. \& Freire, F.A. 2017. Shell use by sympatric hermit crab species in a seasonally open coastal lagoon in Northeastern Brazil. Marine Ecology, 38(5): 1-14, e12451.

Vance, R.R. 1972. Competition and mechanisms of coexistence in three sympatric species of intertidal hermit crabs. Ecology, 53(6): 1062-1074.

Velásquez, M.; Vera-Caripe, J. \& Lira, C. 2017. Crustáceos decápodos asociados a arrecifes de Phragmatopoma sp. (Polychaeta: Sabellariidae) en playa El Horcón, Isla de Margarita, Venezuela. Saber, 29: 249-266.

Werding, B.; Hiller, A. \& Lemaitre, R. 2003. Geographic and distributional patterns of western Atlantic Porcellanidae (Crustacea: Decapoda: Anomura), with an updated list of species. Memoirs of Museum Victoria, 60: 79-85.

Whalen, M.A.; Aquilino, K.M. \& Stachowicz, J.J. 2016. Grazer diversity interacts with biogenic habitat heterogeneity to accelerate intertidal algal succession. Ecology, 97(8): 2136-2146.

Wickham, H.; Hester, J. \& Chang, W. 2018. devtools: Tools to make developing R packages Easier. R package version 1.13.6. https://CRAN.R-project.org/ package $=$ devtools.

Zar, J.H. 2010. Biostatistical Analysis. 5.ed. Upper Saddle River, NJ. PrenticeHall/Pearson. 944p.

Zhao, H.; Sun, C.; Stewart, R.J. \& Waite, J.H. 2005. Cement proteins of the tube-building polychaete Phragmatopoma californica. The Journal of Biological Chemistry, 280(52): 42938-42944.

Zuur, A.F.; leno, E.N. \& Elphick, C.S. 2010. A protocol for data exploration to avoid common statistical problems. Methods in Ecology and Evolution, 1: 3-14. 